\title{
Tropospheric ozone trend over Beijing from 2002-2010: ozonesonde measurements and modeling analysis
}

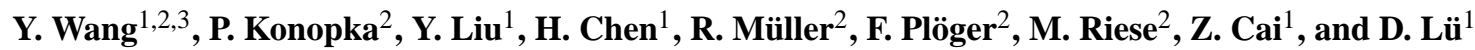 \\ ${ }^{1}$ Key Laboratory of middle Atmosphere and Global Environment Observation, Institute of Atmospheric Physics, Chinese \\ Academy of Sciences, Beijing 100029, China \\ ${ }^{2}$ Institute of Energy and Climate Research: Stratosphere (IEK-7), Forschungszentrum Jülich, 52425 Jülich, Germany \\ ${ }^{3}$ Graduate University of Chinese Academy of Sciences, 100049 Beijing, China
}

Correspondence to: Y. Liu (liuyi@mail.iap.ac.cn)

Received: 7 March 2012 - Published in Atmos. Chem. Phys. Discuss.: 2 May 2012

Revised: 17 August 2012 - Accepted: 1 September 2012 - Published: 18 September 2012

\begin{abstract}
Using a combination of ozonesonde data and numerical simulations of the Chemical Lagrangian Model of the Stratosphere (CLaMS), the trend of tropospheric ozone $\left(\mathrm{O}_{3}\right)$ during 2002-2010 over Beijing was investigated. Tropospheric ozone over Beijing shows a winter minimum and a broad summer maximum with a clear positive trend in the maximum summer ozone concentration over the last decade. The observed significant trend of tropospheric column ozone is mainly caused by photochemical production $\left(3.1 \% \mathrm{yr}^{-1}\right.$ for a mean level of $52 \mathrm{DU})$. This trend is close to the significant trend of partial column ozone in the lower troposphere $(0-3 \mathrm{~km})$ resulting from the enhanced photochemical production during summer $\left(3.0 \% \mathrm{yr}^{-1}\right.$ for a mean level of $23 \mathrm{DU})$. Analysis of the CLaMS simulation shows that transport rather than chemistry drives most of the seasonality of tropospheric ozone. However, dynamical processes alone cannot explain the trend of tropospheric ozone in the observational data. Clearly enhanced ozone values and a negative vertical ozone gradient in the lower troposphere in the observational data emphasize the importance of photochemistry within the troposphere during spring and summer, and suggest that the photochemistry within the troposphere significantly contributes to the tropospheric ozone trend over Beijing during the last decade.
\end{abstract}

\section{Introduction}

Ozone $\left(\mathrm{O}_{3}\right)$ is a critical trace gas in the troposphere, playing an important role in atmospheric chemistry, air quality and climate change. Tropospheric ozone has two sources: photochemical production within the troposphere and downward transport from the stratosphere (Danielsen, 1968). The combined effects of these two sources and the transport processes within the troposphere control the temporal and spatial distribution of tropospheric ozone. These processes render the spatial and temporal ozone variations rather complex, especially in strongly polluted regions where ozone precursors, in particular $\mathrm{NO}_{\mathrm{x}}\left(\mathrm{NO}_{\mathrm{x}}=\mathrm{NO}+\mathrm{NO}_{2}\right)$ and hydrocarbons (Sillman et al., 1990; Kleinman et al., 2002; Wang et al., 2006; Hogrefe et al., 2011), cause enhanced ozone concentrations during photochemically active seasons.

In China, accelerating urbanization and industrial developments are accompanied by a strong increase in emissions of tropospheric pollutants. As a consequence of increased industrial and traffic activity, $\mathrm{NO}_{\mathrm{x}}$ emissions have risen in recent years (e.g., Wang et al., 2004; Ohara et al., 2007), and a significant increase in tropospheric $\mathrm{NO}_{2}$ concentrations from year to year is observed from satellite observations, especially in the fastest growing region of central east China (e.g., Richter et al., 2005; Van der A et al., 2006; Zhang et al., 2007). As a result, an increase in the frequency of ozone pollution events has been observed in the lower troposphere during the photochemically active seasons in these developing suburban and rural areas, suggesting significant detrimental effects of pollution on regional air quality (e.g., 
Gao et al., 2005; Wang et al., 2006; Tie et al., 2009; Dufour et al., 2010). Increasing surface ozone concentrations in the urban and background atmosphere over China, together with an enhanced spatial and temporal variability are apparent in long-term records from surface and aircraft observations (e.g., Ding et al., 2008; Xu et al., 2008; Wang et al., 2009a).

There are fewer long-term records and studies of tropospheric ozone trends for China than for other regions of the Earth. The current understanding of the anthropogenic (versus natural) perturbation to tropospheric ozone in China is far from complete. In this work, we analyzed ozone profiles obtained between $2002-2010$ by a Global Positioning System (GPS) ozonesonde sensor $\left(\mathrm{GPSO}_{3}\right)$, the only ozonesonde station routinely making measurements once per week in North China from 2002 to the present (Bian et al., 2007). Observations of tropospheric ozone concentrations were compared to the output of a multi-year simulation from the Chemical Lagrangian Model of the Stratosphere (CLaMS) (McKenna et al., 2002a,b; Konopka et al., 2004), a chemistry transport model, to investigate the decadal trend and the seasonality of tropospheric ozone over Beijing.

In Sect. 2, we describe the $\mathrm{GPSO}_{3}$ sonde data, the chemistry transport model and the simulation scheme. In Sect. 3, we use ozonesonde profiles and the simulation results to explain the decadal trend of tropospheric ozone and its formation. Section 4 provides a discussion and summary.

\section{Ozonesonde data and chemistry transport model}

\subsection{Ozonesonde data}

The $\mathrm{GPSO}_{3}$ instrument was developed by the Institute of Atmospheric Physics (IAP) of the Chinese Academy of Sciences (CAS). Descriptions of the sensor and the performance of the new system, including inter-comparisons with established sensors, are well documented (Wang et al., 2003; Xuan et al., 2004; Zheng and Li, 2005). Comparison between the $\mathrm{GPSO}_{3}$ and Vaisala ECC sensors showed that the $\mathrm{GPSO}_{3}$ ozonesonde yielded a $20-30 \%$ greater mixing ratio for the troposphere (below $200 \mathrm{hPa}$ ) and 5-10\% lower mixing ratio for the middle stratosphere (above $60 \mathrm{hPa}$ ) but shared a similar variability with ECC ozonesondes, particularly in the UTLS region (Bian et al., 2007). The correlation coefficients for profile by profile between the $\mathrm{GPSO}_{3}$ ozonesondes and the Vaisala ECC ozonesondes are greater than 0.99 (Xuan et al., 2004). Further, in the UTLS region, the agreement between the Atmospheric Infrared Sounder (AIRS) and the $\mathrm{GPSO}_{3}$ ozone measurements is largely with $10 \%$ (Bian et al., 2007).

The ozonesonde data used here were measured with the $\mathrm{GPSO}_{3}$ sensor at regular intervals, once a week at about 14:00 local time (06:00 UTC) over Beijing (116.47 $\mathrm{E}$, $39.8^{\circ} \mathrm{N}$ ), from September 2002 to December 2010. During some intensive observation periods (e.g., 24 March to 10 April 2003), $\mathrm{GPSO}_{3}$ ozonesondes were launched every day. Here, all the ozonesonde profiles were scaled to an independent measurement of the ozone column observed by a Dobson ozone spectrometer at Xianghe station $\left(117.00^{\circ} \mathrm{E}\right.$, $39.77^{\circ} \mathrm{N}$; $55 \mathrm{~km}$ east of Beijing) (WMO, 1995, 1998). If there are no observations available from the Xianghe station, we used total column ozone derived from the Ozone Monitoring Instrument (OMI), the Global Ozone Monitoring Experiment (GOME) or the Scanning Imaging Spectrometer for Atmospheric Chartography (SCIAMACHY) satellite. The maximum altitude for the $\mathrm{GPSO}_{3}$ profile depends on the altitude at which the balloons burst; this is typically between 25 and $35 \mathrm{~km}$. To integrate the column ozone for $\mathrm{GPSO}_{3}$ profiles above observational heights, we use satellite-derived ozone climatology by McPeters et al. (1997). The correction factors (CFs) of this scaling are commonly used as a quality check of ozonesonde measurements (Logan, 1994). Here, the CFs are in the range of $0.8-1.2$, with no statistically significant trend. The mean value of the CFs is $0.97 \pm 0.09$ (mean \pm standard deviation).

The OMI daily determined total column ozone data used to calculate the CFs were downloaded from the NASA (National Aeronautics and Space Administration) earth data website (http://disc.sci.gsfc.nasa.gov/giovanni/overview/instances _atmospheric.html, Level 2G, OMTO3 data set: $2^{\circ} \times 1^{\circ}$ box average). GOME and SCIAMACHY data were obtained from the Institute of Environmental Physics, University of Bremen (http://www.iup.uni-bremen.de/gome/wfdoas/). We use observations centered at Xianghe station using a collocation radius of $300 \mathrm{~km}$.

\subsection{Chemistry transport model}

CLaMS is a modular Lagrangian chemistry transport model (CTM) system that was originally developed for the stratosphere (McKenna et al., 2002a, b; Konopka et al., 2004). Recently, CLaMS was extended through a hybrid coordinate to the surface, incorporating the entire troposphere (Konopka et al., 2007, 2010). Because of the Lagrangian representation of transport, with the intensity of mixing being driven by the strength of flow deformation, the model is particularly well suited for the simulation of tracer transport in the vicinity of strong transport barriers and the associated tracer gradients.

In this paper, we use CLaMS to isolate and quantify the long-term trend of tropospheric ozone caused by transport from the stratosphere. Thus to isolate the transport effect in the model simulation, a CLaMS simulation without ozone chemistry (CLaMS- $\mathrm{PO}_{3}$ : passively transported ozone) is considered. CLaMS- $\mathrm{PO}_{3}$ is set to zero within the lowest model layer near the surface. All air parcels above $\theta=500 \mathrm{~K}$ ozone are prescribed from the Halogen Occultation Experiment (HALOE) climatology (Grooß and Russell, 2005). The HALOE climatology includes seasonal changes of ozone 


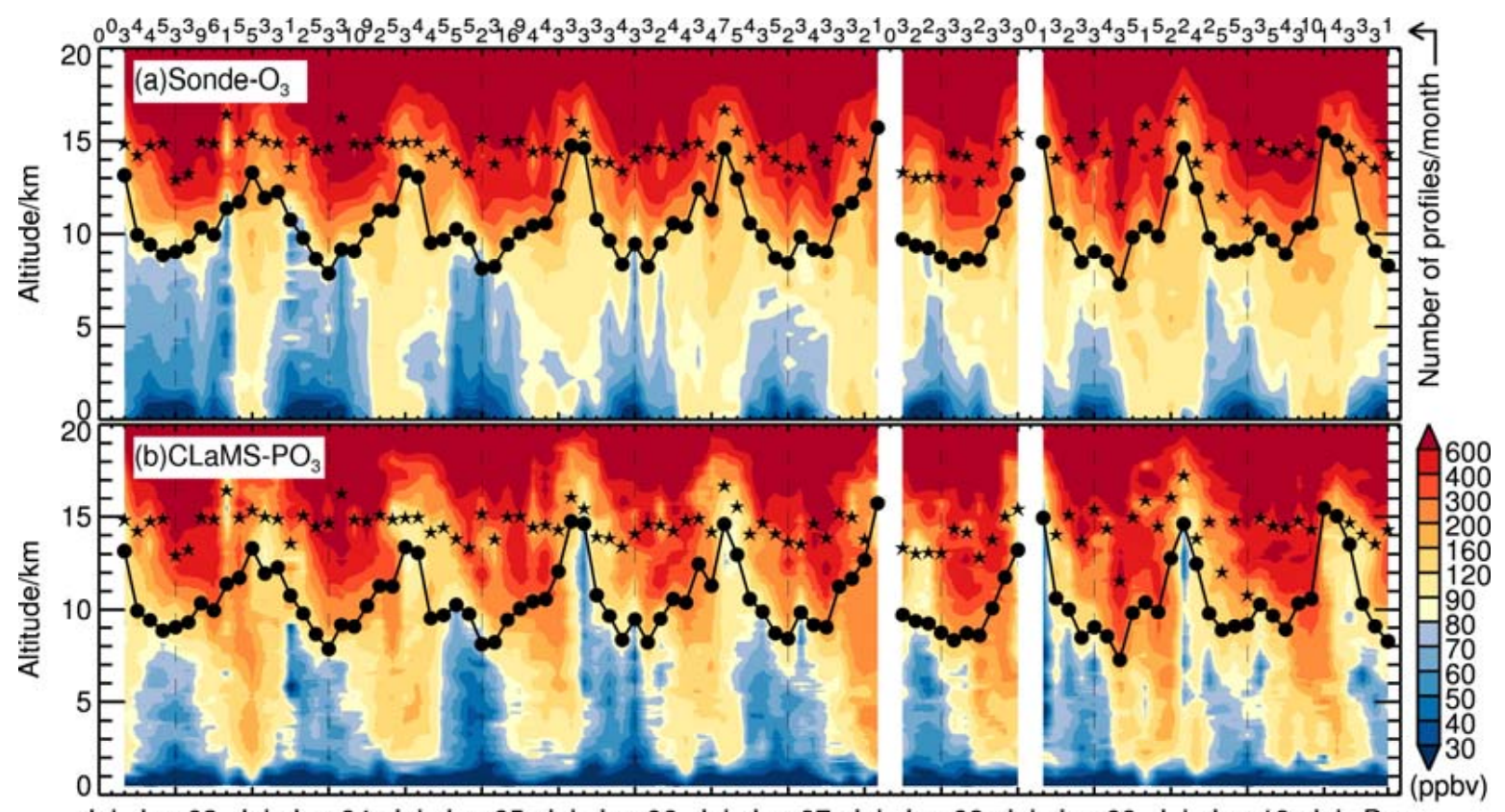

Jul Jan-03 Jul Jan-04 Jul Jan-05 Jul Jan-06 Jul Jan-07 Jul Jan-08 Jul Jan-09 Jul Jan-10 Jul Dec Time/month

Fig. 1. Monthly mean ozone profiles from (a) ozonesonde observation and (b) CLaMS-PO 3 (passively transported ozone) from the CLaMS simulation at the time and location of the measurement, during 2002-2010 in Beijing. The first (LRT1) and second (LRT2) thermal tropopauses are shown as a thick line with solid dots and stars respectively. There were no observations available during September 2007 and August 2008.

with intervals of one month and does not introduce any interannual variations in our simulation. We repeat the first year of the CLaMS simulation (e.g., 2001) 20 times. With this iteration, we start the simulation with self-consistent values. The distribution of passively transported ozone is solely determined by transport from the stratosphere that was validated by comparison to the aircraft- and balloon-borne measurements (Konopka et al., 2004, 2007; Vogel et al., 2011). Therefore, the passively transported ozone offers a reliable reference to quantify changes in ozone concentration in the troposphere caused by transport from the stratosphere. Because transport of ozone from the stratosphere might be slightly overestimated in CLaMS (see below), the passively transported ozone allows to estimate the maximum contribution of transport from the stratosphere.

The CLaMS simulation was carried out for the entire period from 2002 to 2010 and output simulation results daily, with the model's transport driven by the European Centre for Medium-range Weather Forecasts (ECMWF) meteorological ERA-Interim reanalysis (Simmons et al., 2006; Uppala et al., 2008), using the forecast total diabatic heating rate to calculate the vertical cross-isentropic velocity (Ploeger et al., 2010). The specific model setup employed here follows closely the setup described by Konopka et al. (2010), with a horizontal resolution of about $100 \mathrm{~km}$. The model has 45 vertical levels with a maximum vertical resolution of about
$200 \mathrm{~m}$ in the tropopause region. For the comparison with the ozonesonde measurements, the model results were sampled at the time and location of the ozonesonde observations.

\section{Results}

\subsection{Time series: measurements versus simulations}

Figure 1 shows ozonesonde $\left(\right.$ Sonde- $\left.\mathrm{O}_{3}\right)$ and CLaMS (CLaMS- $\mathrm{PO}_{3}$ ) monthly mean ozone mixing ratios from the surface up to $20 \mathrm{~km}$ over Beijing from 2002-2010, together with the heights of the first (LRT1) and the second thermal tropopause (LRT2), calculated from ozonesonde temperature profiles using the definition based on the lapse rate criterion (LRT) (WMO, 1957).

(a) The first tropopause is defined as the lowest level at which the lapse rate decreases to $2^{\circ} \mathrm{C} \mathrm{km}^{-1}$ or less, provided also the average lapse rate between this level and all higher levels within $2 \mathrm{~km}$ does not exceed $2{ }^{\circ} \mathrm{C} \mathrm{km}^{-1}$.

(b) If above the first tropopause the average lapse rate between any level and all higher levels within $1 \mathrm{~km}$ exceeds $3{ }^{\circ} \mathrm{C} \mathrm{km}^{-1}$, then a second tropopause is defined by the same criterion as under (a). 
Throughout the troposphere, ozone concentration detected by ozonesonde (Fig. 1a) exhibited a strong seasonal cycle with a winter minimum and a summer maximum. During winter, the shorter daylight hours and larger solar zenith angles greatly reduce the rate of photochemical ozone production. In the lower troposphere and in the boundary layer, the observed winter minimum ozone concentrations are less than $30 \mathrm{ppbv}$. Summer maximum ozone concentrations frequently exceed $120 \mathrm{ppbv}$ and in a few cases reach 160 ppbv. The enhanced ozone concentrations are comparable to other studies of the region (e.g., Wang et al., 2006, 2009b; Chou et al., 2009), that also consider photochemical ozone production as the primary reason for the elevated concentrations. For example, a 1-h ozone mixing ratio, frequently exceeding $120 \mathrm{ppbv}$ and with a maximum level of $286 \mathrm{ppbv}$, was observed near the surface during June-July 2005 in a mountainous area north of Beijing. These high mixing ratios are caused by emissions from the Beijing urban area (Wang et al., 2006). In the middle and upper troposphere, the Sonde$\mathrm{O}_{3}$ shows a broad summer maximum with clearly increasing values over the last decade.

LRT1 (Fig. 1) reveals strong seasonal cycles with low and high tropopause in winter and summer, respectively. The seasonal variation of LRT2 (Fig. 1) is relative small compare to LRT1. The distance between LRT1 and LRT2 decreases from winter to summer. As we will discuss later, LRT1 is co-located with a strong increase in the vertical ozone concentration gradient, marking this region as the main transport barrier separating the stratosphere from the troposphere. Near the tropopause, downward propagation of enhanced ozone values from the lower stratosphere to the upper troposphere was frequently observed during spring and summer (Fig. 1a).

The CLaMS results at the time and location of the sonde measurements (Fig. 1b) reproduce the main characteristics of the Sonde- $\mathrm{O}_{3}$, in particular from the middle troposphere to the lower stratosphere. Even the detailed structures are resolved fairly well. Consequently, stratospheric ozone is an important source of ozone in the upper troposphere over North China (Chan et al., 2004). The CLaMS- $\mathrm{PO}_{3}$ overestimates the Sonde- $\mathrm{O}_{3}$ data in the middle troposphere and the lower stratosphere for the entire period because of the two possible reasons: First, as a result of the too strong BrewerDobson circulation in the ERA-Interim data driving transport in CLaMS (Ploeger et al., 2010). In ERA-interim the rate of upward transport is almost twice as fast as indicated by observations in the tropics (Dee et al., 2011), which leads to an overestimate of the high latitude downward transport and thus to an overestimate of the contribution of stratospheric ozone to the tropospheric ozone in the extratropical region. Second, due to the absence of tropospheric ozone chemistry in the simulation, ozone destruction in the middle troposphere is not included in the model (e.g., mainly via reactions with water vapor, hydrogen peroxy and hydroxyl radicals, Stevenson et al., 2006).
Differences between CLaMS- $\mathrm{PO}_{3}$ and observations in the troposphere are likely due to the absence of tropospheric ozone chemistry in the model. As discussed above, tropospheric chemistry is excluded for the CLaMS- $\mathrm{PO}_{3}$. Thus, enhanced tropospheric values of CLaMS- $\mathrm{PO}_{3}$ can only originate from the stratosphere. In particular, during spring and summer, ozone-rich air is strongly transported downward from the stratosphere into the troposphere. The values of CLaMS- $\mathrm{PO}_{3}$ in the middle and upper troposphere are of the same order of magnitude as the values of Sonde- $\mathrm{O}_{3}$, indicating that transport rather than chemistry drives the seasonality of tropospheric ozone in the middle and upper troposphere.

From comparison between observation and simulation, both photochemical production within the troposphere and stratospheric downward transport can contribute to the high ozone concentrations in the troposphere. In the following, we will separate these two effects.

\subsection{The seasonality of tropospheric ozone}

The seasonality of tropospheric ozone and its vertical gradient derived from ozonesonde measurements is compared with the CLaMS simulation in Fig. 2. The Sonde- ${ }_{3}$ (Fig. 2a) and the CLaMS- $\mathrm{PO}_{3}$ (Fig. 2b) show the same seasonality with a pronounced maximum in summer and a minimum in winter, although CLaMS overestimates the absolute ozone concentration values, as discussed above. In addition to the ozone mixing ratios, we calculated the vertical gradients (Fig. 2c, d), which display almost the same annual cycle for CLaMS and measurements around the tropopause.

Throughout the year, both LRT1 and LRT2 follow the lines of the strongest change of the gradients (about $80 \mathrm{ppbv} \mathrm{km}^{-1}$ ), identifying in this way the transport barriers. From winter to early summer, a layer with an enhanced ozone gradient $(2-4 \mathrm{~km})$ exists above LRT1, and a thin layer with a reduced ozone gradient is located below LRT2. This layer of enhanced ozone gradient suggests frequent intrusion of ozone from the lower stratosphere to the troposphere. These remarkable features suggest a key role of dynamical processes in modulating the distribution of tropospheric ozone over Beijing.

The sharp peak of high ozone concentrations in the lower troposphere in June (Fig. 2a) is consistent with the ozone enhancements in June over Beijing measured from aircraft (Ding et al., 2008), which are attributed to photochemical production. Wang et al. (2011) also suggest that Chinese pollution ozone has a peak of 20-25 ppbv in June north of the Yangtze River, which explains the peaks of high ozone concentrations in the lower troposphere in June. In particular, a clear signature of enhanced ozone concentrations (Fig. 2a) and a negative ozone gradient (values with the dark blue contour reach -16 ppbv km${ }^{-1}$ in Fig. $2 c$ ) are found in the lower troposphere but are not present in the CLaMS passive ozone field. These results emphasize the importance of photochemistry within the lower troposphere during spring and summer. 


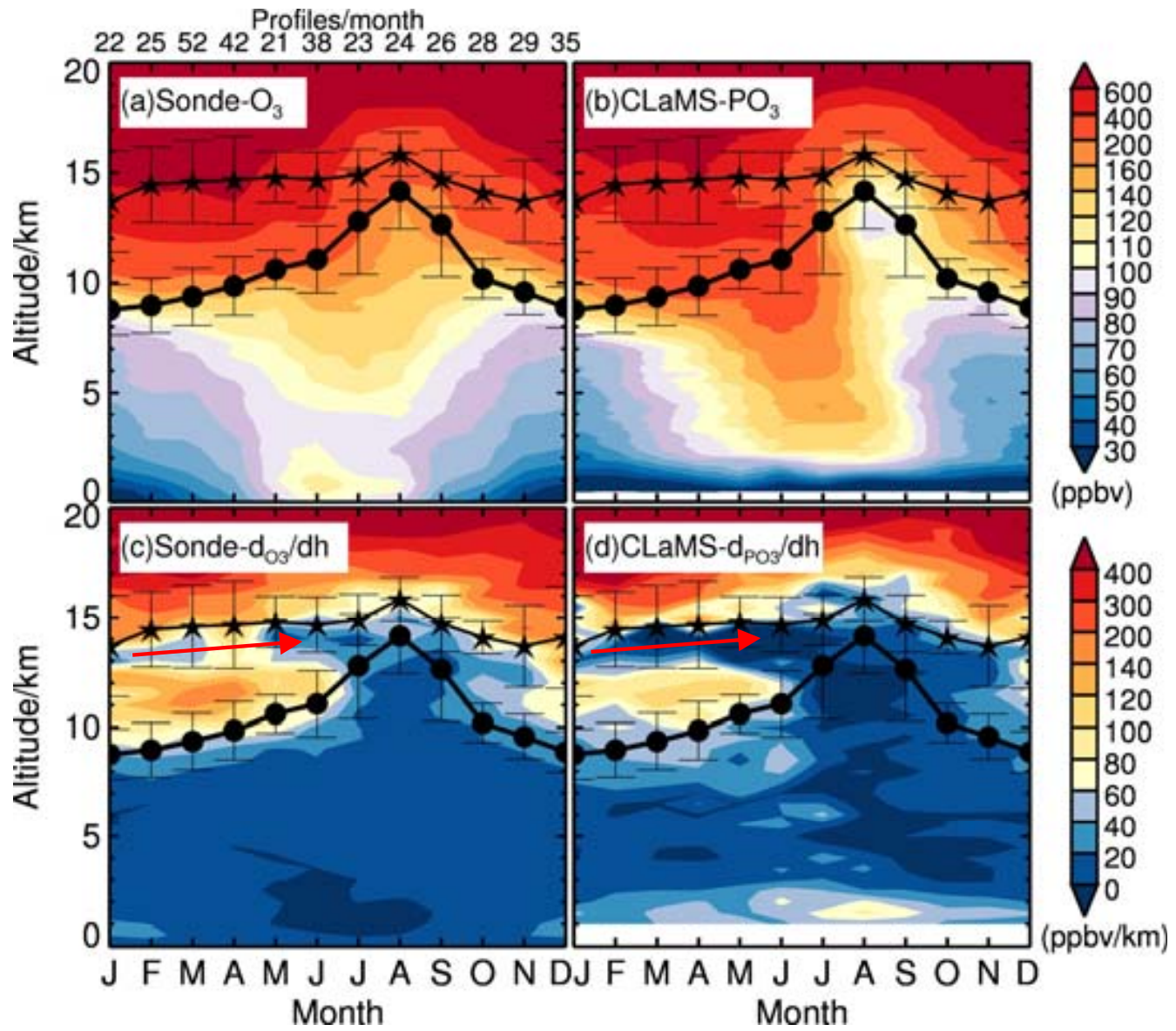

Fig. 2. The seasonality of ozone from (a) ozonesonde observation, (b) CLaMS-PO 3 (passively transported ozone) from CLaMS simulation at the time and location of the measurement, and their corresponding (c, d) vertical gradients during 2002-2010 at Beijing. The first (LRT1) and second (LRT2) thermal tropopauses are shown as a thick line with solid dots and stars, respectively. The error bars are standard deviations $( \pm \sigma)$. The red arrow shows a thin layer with a reduced ozone gradient below LRT2.

The relative contribution of stratospheric ozone to the tropospheric ozone budget is a controversial issue and has been debated for many years (e.g., Kim and Lee, 2010; He et al., 2011). Our analysis shows that both stratospheric downward transport and photochemical production within the troposphere influence the distribution of tropospheric ozone over Beijing. In particular, in the lower troposphere, enhanced ozone concentrations in spring and summer are most likely to originate from the photochemical production. We show in the next Section that, for Beijing during spring and summer, there is a positive trend of enhanced lower tropospheric ozone concentrations over the last decade.

\subsection{Tropospheric ozone trend}

To separate the tropospheric production of ozone from the effect of stratospheric sources, we integrated the Sonde- $\mathrm{O}_{3}$ and the CLaMS-PO $\mathrm{PO}_{3}$ data from the surface to LRT1 for each profile and averaged the integrated tropospheric column ozone
(TCO) to monthly means. Logan (1994) studied trends in the vertical distribution of ozone using ozonesonde data and showed that with weekly sampling representative monthly means can be obtained. For our research, most of the months have $3-5$ soundings and this roughly meets the criterion. We compared monthly mean TCO from the Sonde- $\mathrm{O}_{3}$ and OMI satellite $\left( \pm 1^{\circ}\right.$ box average centered at Beijing ozonesonde station and sampled more than 20 times per month) during 2004-2008. The OMI TCO data are made by Liu et al. (2010). The high correlation coefficient $(R=0.89)$ and small relative mean bias (less than $19 \%$ ) between sonde and OMI suggest that the sonde observation agrees well with OMI observation. The mean of soundings for each month can thus be assumed to represent a monthly mean. It appears that some months during the observation period have only $1-$ 2 soundings. We have tested that removing of such data sets from the considered time series the trends in ozone are not 


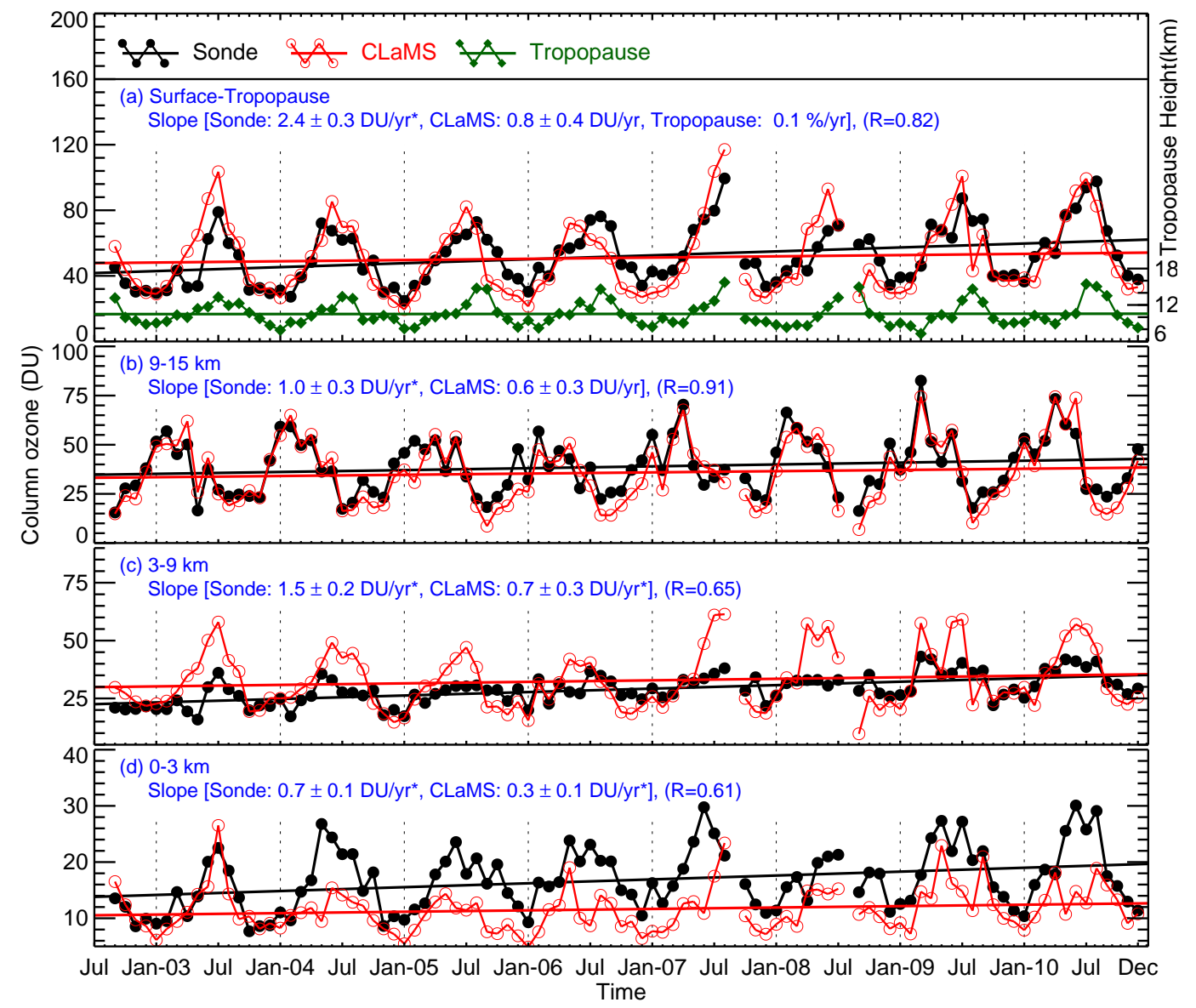

Fig. 3. Trends of monthly mean partial column ozone for (a) the whole troposphere (surface-tropopause), (b) 9-15 km layer, (c) 3-9 km layer and (d) 0-3 km layer from observation (Sonde) and simulation (CLaMS) during 2002-2010, together with the first (LRT1) thermal tropopause. The numerical values for the slopes with symbol “*” pass the $95 \%$ significance criterion. The number $R$ is the correlation coefficient between observation and simulation. There were no observations available during September 2007 and August 2008.

sensitive to the sampling size in our case by removing those months with only $1-2$ soundings.

The TCO for ozonesonde (Sonde $\mathrm{TCO}_{\text {) }}$ includes photochemical production within the troposphere and downward transport from the stratosphere. The TCO for CLaMS ( $\left.\mathrm{CLaMS}_{\mathrm{TCO}}\right)$ is only influenced by transport from the stratosphere and thus does not contain any contribution from tropospheric chemistry. Because the values of TCO strongly depend on the column height, we also calculated the trend of LRT1. There is a strong seasonal cycle in ozone and tropopause height. For the trend calculation, each data set was deseasonalized by subtracting the average of all monthly data for a given month from the original data of the same month, and the trend was calculated by linear regression using the deseasonalized data. Figure 3a shows the time series and the trends of TCO and LRT1 from 2002 to 2010.

The high correlation coefficient $(0.82)$ between the Sonde $_{\mathrm{TCO}}$ and the $\mathrm{CLaMS}_{\mathrm{TCO}}$ indicates that the main characteristics of tropospheric ozone are well captured by the model. The trends of the Sonde $\mathrm{TCO}$ and the $\mathrm{CLaMS}_{\mathrm{TCO}}$ are 2.4 $\mathrm{DU} \mathrm{yr}^{-1}$ and $0.8 \mathrm{DU} \mathrm{yr}^{-1}$ or $4.6 \% \mathrm{yr}^{-1}$ and $1.5 \% \mathrm{yr}^{-1}$ for a mean level of $52 \mathrm{DU}$, respectively. Here, the mean level is the average value of the Sonde Only the trend of Sonde TCO $_{\text {passes the }} 95 \%$ significance test, according to the Student's $t$ test. Because there is no trend for LRT1 $\left(0.1 \% \mathrm{yr}^{-1}\right.$ with no statistical significance), these TCO trends can't originate from the long-term variation of LRT1.

To quantify these trends for different altitudes, the troposphere is divided into three layers: $9-15 \mathrm{~km}$ (upper troposphere and lower stratosphere), 3-9 km (middle troposphere) and $0-3 \mathrm{~km}$ (lower troposphere); the Sonde- $\mathrm{O}_{3}$ and the $\mathrm{CLaMS}-\mathrm{PO}_{3}$ are integrated within these layers. Figure $3 \mathrm{~b}-\mathrm{d}$ shows the integrated partial column ozone (PCO) of the observation (Sonde $\mathrm{PCO}$ ) and simulation $\left(\mathrm{CLaMS}_{\mathrm{PCO}}\right)$ for each layer. The large correlation coefficients $(0.91,0.65$ and 0.61 , for the three layers respectively) between the Sonde $\mathrm{PCO}$ and the CLaMSPCO demonstrate that the simulation reproduces the main characteristics of tropospheric 
Table 1. Trends of monthly mean partial column ozone from observation (Sonde) and simulation (CLaMS) during 2002-2010 ${ }^{\mathrm{a}}$.

\begin{tabular}{|c|c|c|c|c|c|c|c|c|}
\hline \multirow[t]{2}{*}{ Layer } & \multicolumn{2}{|c|}{ Mean (DU) } & \multicolumn{2}{|c|}{ Absolute trend (DU) } & \multicolumn{3}{|c|}{ Relative trend (\%) } & \multirow[t]{2}{*}{$R$} \\
\hline & Sonde & CLaMS & Sonde & CLaMS & Sonde & CLaMS & Diff & \\
\hline $\mathrm{TCO}$ & 52 & 51 & $* 2.4 \pm 0.3$ & $0.8 \pm 0.4$ & $* 4.6$ & 1.5 & 3.1 & 0.82 \\
\hline $9-15 \mathrm{~km}$ & 39 & 36 & $* 1.0 \pm 0.3$ & $0.6 \pm 0.3$ & $* 2.6$ & 1.5 & 1.1 & 0.91 \\
\hline $3-9 \mathrm{~km}$ & 29 & 33 & $* 1.5 \pm 0.2$ & $* 0.7 \pm 0.3$ & $* 5.2$ & $* 2.4$ & 2.8 & 0.65 \\
\hline $0-3 \mathrm{~km}$ & 17 & 12 & $* 0.7 \pm 0.1$ & $* 0.3 \pm 0.1$ & $* 4.1$ & $* 1.8$ & 2.3 & 0.61 \\
\hline
\end{tabular}

${ }^{\mathrm{a}}$ Absolute trends (slope \pm standard error) for the whole troposphere (TCO), 9-15 km layer, 3-9 km layer and 0-3 km layer are shown in the table, together with the correlation coefficients $(\mathrm{R})$ between Sonde and CLaMS. The trends with symbol “*” pass the $95 \%$ significance criterion. The relative trend column list Absolute(trend)/Sonde(mean) $\times 100 \%$ and the difference of relative trends (Diff) between Sonde and CLaMS

ozone concentration from the lower stratosphere to the surface. Especially the good agreement in the $9-15 \mathrm{~km}$ layer (Fig. 3b) suggests that CLaMS successfully simulates crosstropopause transport. The correlation coefficients decrease with altitude and the differences between the Sonde $\mathrm{PCO}$ and the CLaMS $\mathrm{PCO}$ become larger, especially during spring and summer. These observations suggest that the photochemical ozone production becomes increasingly important with a decrease in altitude within the troposphere. Table 1 summarizes the trends of monthly mean PCO from the observation and the simulation. In the $9-15 \mathrm{~km}$ layer, the trends of the

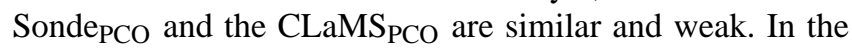
3-9 km layer, the trends of the Sonde $\mathrm{PCO}$ and CLaMS $\mathrm{PCO}$ are 1.5 $\mathrm{DU} \mathrm{yr}^{-1}$ and $0.7 \mathrm{DU} \mathrm{yr}^{-1}$ or $5.2 \% \mathrm{yr}^{-1}$ and $2.4 \% \mathrm{yr}^{-1}$ for a mean level of $29 \mathrm{DU}$, respectively. In the $0-3 \mathrm{~km}$ layer, the trends of the Sonde $\mathrm{PCO}$ and CLaMS $\mathrm{PCO}$ are $0.7 \mathrm{DU} \mathrm{yr}^{-1}$ and $0.3 \mathrm{DU} \mathrm{yr}^{-1}$ or $4.1 \% \mathrm{yr}^{-1}$ and $1.8 \% \mathrm{yr}^{-1}$ for a mean level of $17 \mathrm{DU}$, respectively. In the lowest two layers, all the trends pass the $95 \%$ significance criterion, but the trends of Sonde $\mathrm{PCO}$ are much stronger than the trends of CLaMS $\mathrm{PCO}$. The trends of CLaMS $\mathrm{PCO}$ are probably caused by the accelerated Brewer-Dobson circulation which was lead to an increase in stratosphere-to-troposphere ozone flux with a maximum positive trend between 2000 and 2030 (Hegglin and Shepherd, 2009). Sonde $\mathrm{PCO}$ values for the $0-3 \mathrm{~km}$ layer (Fig. 3d) were low in the summer of 2008. This is likely because the Olympic Games took place in Beijing from August to September 2008 and strict controls were placed on pollutant emissions from industry and road traffic in Beijing and the surrounding provinces. Satellite measurements over Beijing between July and September 2008 showed a $43 \%$ reduction in tropospheric column $\mathrm{NO}_{2}$, compared to the previous three years (Witte et al., 2009). The related reduction in emissions of ozone precursors, significantly contributed to the observed decrease in ozone during August 2008 (Wang et al., 2009c). Furthermore, the average ozone concentration in the plumes observed at a rural site about $50 \mathrm{~km}$ north of the center of Beijing decreased by $8.2 \%$ in 2008 compared with 2005 (Wang et al., 2010).

The best agreement between Sonde $\mathrm{PCO}$ and CLaMS $\mathrm{PCO}$ values was found in the upper troposphere and lower strato- sphere. Values of Sonde $\mathrm{PCO}$ and $\mathrm{CLaMS}_{\mathrm{PCO}}$ are comparable in the lower and middle troposphere during winter, but the differences between them are much greater during summer. To discuss these differences in more detail, we divided the whole time series into two time periods: winter (DecemberMarch) and summer (May-August).

Figure 4 shows the PCO trends and time series for the two seasons in the lowest two layers. The CLaMS simulations reproduce the general characteristics of the observations during winter. This is shown by the high correlation coefficients $(0.79$ and 0.61$)$ in both layers due to the key role of dynamical processes modulating the distribution of tropospheric ozone through this period. The high correlation results from the capability of CLaMS to realistically simulate ozone pattern caused by downward transport from the stratosphere, because photochemical ozone production is limited by the weak sunlight intensity during winter. We attribute the poor correlation coefficients $(0.40$ and 0.08$)$ between observation and simulation during summer to the increase in sunlight intensity and the photochemical ozone production within the troposphere. It is worth noting that the simulated values of the PCO are larger in the 3-9 km layer and smaller in the $0-3 \mathrm{~km}$ layer compared to the observations. The elevated and depressed ozone concentrations in the model in the middle and lower troposphere, respectively, are caused by the absence of tropospheric ozone chemistry in the simulation. In particular, it is expected that ozone will be destroyed and thereby removed from the middle troposphere (e.g., mainly via reactions with water vapor, hydrogen peroxy and hydroxyl radicals, Stevenson et al., 2006) and created in the lower troposphere (e.g., when carbon monoxide and hydrocarbons are photo-oxidized in the presence of $\mathrm{NO}_{\mathrm{x}}$, Crutzen, 1973; Liu et al., 1980). The seasonal comparison shown here highlights the importance of ozone chemistry within the troposphere during summer.

Table 2 summarizes the trends of PCO during winter and summer. All the trends of Sonde $\mathrm{PCO}$ calculated for winter and summer pass the $95 \%$ significance criterion. The trends of CLaMSPCO, on the other hand, are much weaker and only the winter trend $\left(1.6 \mathrm{DU} \mathrm{yr}^{-1}\right.$ or $5.8 \% \mathrm{yr}^{-1}$ for a mean level of $26 \mathrm{DU}$ ) in the $3-9 \mathrm{~km}$ layer passes the $95 \%$ 

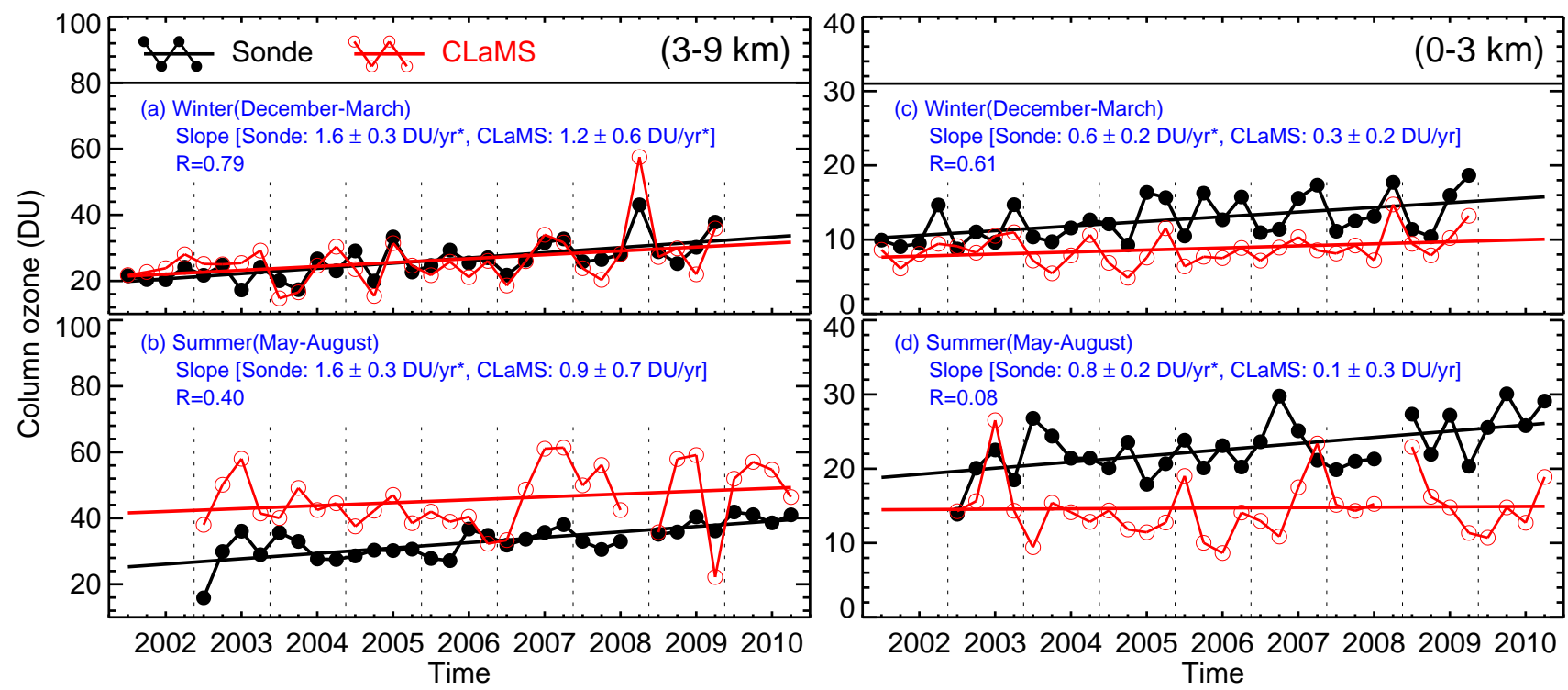

Fig. 4. Trends of monthly mean partial column ozone for 3-9 km layer and 0-3 km layer in winter (December-March) and summer (MayAugust) from observation (Sonde) and simulation (CLaMS) during 2002-2010. The numerical values for the slopes with symbol "*” pass the $95 \%$ significance criterion. The number $R$ is the correlation coefficient between observation and simulation. There were no observations available during August 2008.

Table 2. Trends of monthly mean partial column ozone from observation (Sonde) and simulation (CLaMS) in winter (w: December-March) and summer (s: May-August) during 2002-2010 .

\begin{tabular}{rrrrrrrrr}
\hline \multirow{2}{*}{ Layer } & \multicolumn{2}{c}{ Mean (DU) } & \multicolumn{2}{c}{ Absolute trend (DU) } & \multicolumn{2}{c}{ Relative trend (\%) } & $R$ \\
\cline { 2 - 7 } & Sonde & CLaMS & Sonde & CLaMS & Sonde & CLaMS & Diff & \\
\hline TCO (w) & 38 & 34 & $* 2.1 \pm 0.9$ & $1.1 \pm 1.1$ & $* 5.5$ & 2.9 & 2.6 & 0.70 \\
9-15 km (w) & 49 & 43 & $0.5 \pm 0.9$ & $0.2 \pm 0.9$ & 1.0 & 0.4 & 0.6 & 0.87 \\
$3-9$ km (w) & 26 & 26 & $* 1.6 \pm 0.3$ & $* 1.2 \pm 0.6$ & $* 6.2$ & $* 5.8$ & 0.4 & 0.79 \\
$0-3 \mathrm{~km}(\mathrm{w})$ & 13 & 9 & $* 0.6 \pm 0.2$ & $0.3 \pm 0.2$ & $* 4.6$ & 2.3 & 2.3 & 0.61 \\
\hline TCO (s) & 70 & 77 & $* 3.4 \pm 0.8$ & $1.4 \pm 1.3$ & $* 4.9$ & 2.0 & 2.9 & 0.54 \\
9-15 km (s) & 34 & 36 & $1.6 \pm 0.9$ & $1.5 \pm 1.2$ & 4.7 & 4.4 & 0.3 & 0.92 \\
$3-9 \mathrm{~km}(\mathrm{~s})$ & 33 & 46 & $* 1.6 \pm 0.3$ & $0.9 \pm 0.7$ & $* 4.8$ & 2.7 & 2.1 & 0.40 \\
$0-3 \mathrm{~km}(\mathrm{~s})$ & 23 & 15 & $* 0.8 \pm 0.2$ & $0.1 \pm 0.3$ & $* 3.4$ & 0.4 & 3.0 & 0.08 \\
\hline
\end{tabular}

${ }^{\mathrm{a}}$ Absolute trends (slope \pm standard error) for the whole troposphere (TCO), 9-15 km layer, 3-9 km layer and 0-3 km layer are shown in the table, together with the correlation coefficients (R) between Sonde and CLaMS. The trends with symbol "*" pass the $95 \%$ significance criterion. The relative trend column list Absolute(trend)/Sonde(mean) $\times 100 \%$ and the difference of relative trends (Diff) between Sonde and CLaMS.

significance criterion. This significant trend in the simulation during winter indicates a trend of downward transport ozone from the stratosphere, as discussed above (Hegglin and Shepherd, 2009).

By subtracting the CLaMS trends from the sonde trends, we infer the trends resulting from the photochemical production within the troposphere to be $3.1 \% \mathrm{yr}^{-1}$ for the tropospheric column ozone, $2.3 \% \mathrm{yr}^{-1}$ for the partial column ozone in the lower troposphere and $2.8 \% \mathrm{yr}^{-1}$ for the partial column ozone in the middle troposphere for the entire time series. For seasonal analysis of the partial column ozone in different altitudes, the largest photochemically produced trend occurs in the lower troposphere $\left(3.0 \% \mathrm{yr}^{-1}\right)$ during summer.

\section{Conclusions}

Using ozonesonde data and a chemistry transport model (CLaMS), the long-term trend of tropospheric ozone over Beijing from 2002-2010 was quantified and the processes causing the trend were investigated. Tropospheric ozone concentrations show a winter minimum and a broad summer 
maximum with a clear positive trend over the last decade. The significant trend of tropospheric column ozone for the entire time series is $4.6 \% \mathrm{yr}^{-1}$ for a mean level of $52 \mathrm{DU}$. The significant trend of partial column ozone in the lower troposphere in summer is $3.4 \% \mathrm{yr}^{-1}$ for a mean level of $23 \mathrm{DU}$. Most of the trend is caused by photochemical production $\left(\sim 3 \% \mathrm{yr}^{-1}\right)$. A similar positive trend in ozone in the lower troposphere was recently found by Ding et al. (2008) from aircraft observations over Beijing (approximately $4 \% \mathrm{yr}^{-1}$ for a mean level of $75 \mathrm{ppbv}$ during May-July from 1995 to 2005), in contrast to a flat or a negative trend over Tokyo, New York City, and Paris. The model results show trends that are weaker than those seen in the observations. These model trends come from the increased downward ozone flux from the stratosphere. This is particularly true for the middle troposphere during winter and this trend partly overlays with the trend in the observations.

The comparison between observation and simulation indicates that transport rather than chemistry drives much of the seasonality of tropospheric ozone. However, transport processes alone cannot explain the significant trend of tropospheric ozone in the observations. We have shown that photochemical ozone production strongly contributes to the tropospheric ozone increase during spring and summer. Although photochemistry is neglected in the model, the simulated ozone values show a weak positive trend. This trend can be explained by an increase in the downward ozone flux from the stratosphere. It also contributes (by $\sim 56 \%$ in the middle troposphere and $\sim 13 \%$ in the lower troposphere) to the trend in the observations during spring and summer, especially in the middle troposphere during winter (by $\sim 75 \%$ ).

Acknowledgements. This work was funded by the National Basic Research Program of China (grant 2010CB428604), the National Science Foundation of China (grant 41075014 and 40830102) and the $\mathrm{PhD}$ program of Forschungszentrum Jülich. We thank Gengchen Wang, Yuejian Xuan, Xiaowei Wan and Jianchun Bian for their contributions to Beijing ozonesonde observation. We thank J.-U. Grooß and A. Kunz for their very helpful comments. The European Centre for Medium-Range Weather Forecasts (ECMWF) is acknowledged for meteorological data support. We thank NASA (National Aeronautics and Space Administration) earth data website and Institute of Environmental Physics, University of Bremen for supplying the total ozone data.

Edited by: X. Tie

\section{References}

Bian, J., Gettelman, A., Chen, H., and Pan, L. L.: Validation of satellite ozone profile retrievals using Beijing ozonesonde data, J. Geophys. Res., 112, D06305, doi:10.1029/2006jd007502, 2007. Chan, C. Y., Zheng, X. D., Chan, L. Y., Cui, H., Ginn, E. W. L., Leung, Y. K., Lam, H. M., Zheng, Y. G., Qin, Y., Zhao,
C. S., Wang, T., Blake, D. R., and Li, Y. S.: Vertical profile and origin of wintertime tropospheric ozone over China during the PEACE-A period, J. Geophys. Res., 109, D23S06, doi:10.1029/2004jd004581, 2004.

Chou, C. C. K., Tsai, C.-Y., Shiu, C.-J., Liu, S. C., and Zhu, T.: Measurement of $\mathrm{NO}_{\mathrm{y}}$ during Campaign of Air Quality Research in Beijing 2006 (CAREBeijing-2006): Implications for the ozone production efficiency of $\mathrm{NO}_{\mathrm{x}}$, J. Geophys. Res., 114, D00G01, doi:10.1029/2008jd010446, 2009.

Crutzen, P.: A discussion of the chemistry of some minor constituents in the stratosphere and troposphere, Pure Appl. Geophys., 106, 1385-1399, doi:10.1007/bf00881092, 1973.

Danielsen, E. F.: Stratospheric-tropospheric exchange based on radioactivity, ozone and potential vorticity, J. Atmos. Sci., 25, 502$518,1968$.

Dee, D. P., Uppala, S. M., Simmons, A. J., Berrisford, P., Poli, P., Kobayashi, S., Andrae, U., Balmaseda, M. A., Balsamo, G., Bauer, P., Bechtold, P., Beljaars, A. C. M., van de Berg, L., Bidlot, J., Bormann, N., Delsol, C., Dragani, R., Fuentes, M., Geer, A. J., Haimberger, L., Healy, S. B., Hersbach, H., Hólm, E. V., Isaksen, L., Kållberg, P., Köhler, M., Matricardi, M., McNally, A. P., Monge-Sanz, B. M., Morcrette, J. J., Park, B. K., Peubey, C., de Rosnay, P., Tavolato, C., Thépaut, J. N., and Vitart, F.: The ERA-Interim reanalysis: configuration and performance of the data assimilation system, Q. J. Roy. Meteorol. Soc., 137, 553597, doi:10.1002/qj.828, 2011.

Ding, A. J., Wang, T., Thouret, V., Cammas, J.-P., and Nédélec, P.: Tropospheric ozone climatology over Beijing: analysis of aircraft data from the MOZAIC program, Atmos. Chem. Phys. Discuss., 7, 9795-9828, doi:10.5194/acpd-7-9795-2007, 2007.

Dufour, G., Eremenko, M., Orphal, J., and Flaud, J. M.: IASI observations of seasonal and day-to-day variations of tropospheric ozone over three highly populated areas of China: Beijing, Shanghai, and Hong Kong, Atmos. Chem. Phys., 10, 3787 3801, doi:10.5194/acp-10-3787-2010, 2010.

Gao, J., Wang, T., Ding, A., and Liu, C.: Observational study of ozone and carbon monoxide at the summit of mount Tai (1534 m a.s.1.) in central-eastern China, Atmos. Environ., 39, 4779-4791, doi:10.1016/j.atmosenv.2005.04.030, 2005.

Grooß, J. U. and Russell III, J. M.: Technical note: A stratospheric climatology for $\mathrm{O}_{3}, \mathrm{H}_{2} \mathrm{O}, \mathrm{CH}_{4}, \mathrm{NO}_{\mathrm{x}}, \mathrm{HCl}$ and $\mathrm{HF}$ derived from HALOE measurements, Atmos. Chem. Phys., 5, 2797-2807, doi:10.5194/acp-5-2797-2005, 2005.

He, H., Tarasick, D. W., Hocking, W. K., Carey-Smith, T. K., Rochon, Y., Zhang, J., Makar, P. A., Osman, M., Brook, J., Moran, M. D., Jones, D. B. A., Mihele, C., Wei, J. C., Osterman, G., Argall, P. S., McConnell, J., and Bourqui, M. S.: Transport analysis of ozone enhancement in Southern Ontario during BAQS-Met, Atmos. Chem. Phys., 11, 2569-2583, doi:10.5194/acp-11-25692011, 2011.

Hegglin, M. I., and Shepherd, T. G.: Large climate-induced changes in ultraviolet index and stratosphere-to-troposphere ozone flux, Nat. Geosci., 2, 687-691, doi:10.1038/NGEO604, 2009.

Hogrefe, C., Hao, W., Zalewsky, E. E., Ku, J. Y., Lynn, B., Rosenzweig, C., Schultz, M. G., Rast, S., Newchurch, M. J., Wang, L., Kinney, P. L., and Sistla, G.: An analysis of long-term regional-scale ozone simulations over the Northeastern United States: variability and trends, Atmos. Chem. Phys., 11, 567-582, doi:10.5194/acp-11-567-2011, 2011. 
Kim, J. and Lee, H.: What causes the springtime tropospheric ozone maximum over Northeast Asia?, Adv. Atmos. Sci., 27, 543-551, doi:10.1007/s00376-009-9098-z, 2010.

Kleinman, L. I., Daum, P. H., Imre, D., Lee, Y. N., Nunnermacker, L. J., Springston, S. R., Weinstein-Lloyd, J., and Rudolph, J.: Ozone production rate and hydrocarbon reactivity in 5 urban areas: A cause of high ozone concentration in Houston, Geophys. Res. Lett., 29, 1467, doi:10.1029/2001g1014569, 2002.

Konopka, P., Steinhorst, H.-M., Grooß, J.-U., Günther, G., Müller, R., Elkins, J. W., Jost, H.-J., Richard, E., Schmidt, U., Toon, G., and McKenna, D. S.: Mixing and ozone loss in the 1999-2000 Arctic vortex: Simulations with the three-dimensional Chemical Lagrangian Model of the Stratosphere (CLaMS), J. Geophys. Res., 109, D02315, doi:10.1029/2003jd003792, 2004.

Konopka, P., Günther, G., Müller, R., dos Santos, F. H. S., Schiller, C., Ravegnani, F., Ulanovsky, A., Schlager, H., Volk, C. M., Viciani, S., Pan, L. L., McKenna, D. S., and Riese, M.: Contribution of mixing to upward transport across the tropical tropopause layer (TTL), Atmos. Chem. Phys., 7, 3285-3308, doi:10.5194/acp-7-3285-2007, 2007.

Konopka, P., Grooß, J.-U., Günther, G., Ploeger, F., Pommrich, R., Müller, R., and Livesey, N.: Annual cycle of ozone at and above the tropical tropopause: observations versus simulations with the Chemical Lagrangian Model of the Stratosphere (CLaMS), Atmos. Chem. Phys., 10, 121-132, doi:10.5194/acp-10-121-2010, 2010.

Liu, S. C., Kley, D., McFarland, M., Mahlman, J. D., and Levy, H., II: On The Origin of Tropospheric Ozone, J. Geophys. Res., 85, 7546-7552, doi:10.1029/JC085iC12p07546, 1980.

Liu, X., Bhartia, P. K., Chance, K., Spurr, R. J. D., and Kurosu, T. P.: Ozone profile retrievals from the Ozone Monitoring Instrument, Atmos. Chem. Phys., 10, 2521-2537, doi:10.5194/acp-10-25212010, 2010.

Logan, J. A.: Trends in the vertical distribution of ozone: An analysis of ozonesonde data, J. Geophys. Res., 99, 25553-25585, doi:10.1029/94jd02333, 1994.

McKenna, D. S., Grooß, J.-U., Günther, G., Konopka, P., Müller, R., Carver, G., and Sasano, Y.: A new Chemical Lagrangian Model of the Stratosphere (CLaMS) 2. Formulation of chemistry scheme and initialization, J. Geophys. Res., 107, 4256, doi:10.1029/2000jd000113, 2002a.

McKenna, D. S., Konopka, P., Grooß, J.-U., Günther, G., Müller, R., Spang, R., Offermann, D., and Orsolini, Y.: A new Chemical Lagrangian Model of the Stratosphere (CLaMS) 1. Formulation of advection and mixing, J. Geophys. Res., 107, 4309, doi:10.1029/2000jd000114, 2002b.

McPeters, R. D., Labow, G. J., and Johnson, B. J.: A satellitederived ozone climatology for balloonsonde estimation of total column ozone, J. Geophys. Res., 102, 8875-8885, doi:10.1029/96jd02977, 1997.

Ohara, T., Akimoto, H., Kurokawa, J., Horii, N., Yamaji, K., Yan, $\mathrm{X}$., and Hayasaka, T.: An Asian emission inventory of anthropogenic emission sources for the period 1980-2020, Atmos. Chem. Phys., 7, 4419-4444, doi:10.5194/acp-7-4419-2007, 2007.

Ploeger, F., Konopka, P., Günther, G., Grooß, J. U., and Müller, R.: Impact of the vertical velocity scheme on modeling transport in the tropical tropopause layer, J. Geophys. Res., 115, D03301, doi:10.1029/2009jd012023, 2010.
Richter, A., Burrows, J. P., Nusz, H., Granier, C., and Niemeier, U.: Increase in tropospheric nitrogen dioxide over China observed from space, Nature, 437, 129-132, 2005.

Sillman, S., Logan, J. A., and Wofsy, S. C.: The Sensitivity of Ozone to Nitrogen Oxides and Hydrocarbons in Regional Ozone Episodes, J. Geophys. Res., 95, 1837-1851, doi:10.1029/JD095iD02p01837, 1990.

Simmons, A., Uppala, S., Dee, D., and Kobayashi, S.: ERA-Interim: New ECMWF reanalysis products from 1989 onwards, ECMWF Newsletter, 110, 25-35, 2006.

Stevenson, D. S., Dentener, F. J., Schultz, M. G., Ellingsen, K., Noije, T. P. C. v., Wild, O., Zeng, G., Amann, M., Atherton, C. S., Bell, N., Bergmann, D. J., Bey, I., Butler, T., Cofala, J., Collins, W. J., Derwent, R. G., Doherty, R. M., Drevet, J., Eskes, H. J., Fiore, A. M., Gauss, M., Hauglustaine, D. A., Horowitz, L. W., Isaksen, I. S. A., Krol, M. C., Lamarque, J. F., Lawrence, M. G., Montanaro, V., Müller, J. F., Pitari, G., Prather, M. J., Pyle, J. A., Rast, S., Rodriguez, J. M., Sanderson, M. G., Savage, N. H., Shindell, D. T., Strahan, S. E., Sudo, K., and Szopa, S.: Multimodel ensemble simulations of presentday and near-future tropospheric ozone, J. Geophys. Res., 111, D08301, doi:10.1029/2005JD006338, 2006.

Tie, X., Geng, F., Peng, L., Gao, W., and Zhao, C.: Measurement and modeling of $\mathrm{O}_{3}$ variability in Shanghai, China: Application of the WRF-Chem model, Atmos. Environ., 43, 4289-4302, doi:10.1016/j.atmosenv.2009.06.008, 2009.

Uppala, S., Dee, D., Kobayashi, S., Berrisford, P., and Simmons, A.: Towards a climate data assimilation system: status update of ERA-Interim, ECMWF Newsletter, 115, 12-18, 2008.

Van der A, R. J., Peters, D. H. M. U., Eskes, H., Boersma, K. F., Roozendael, M. V., Smedt, I. D., and Kelder, H. M.: Detection of the trend and seasonal variation in tropospheric $\mathrm{NO}_{2}$ over China, J. Geophys. Res., 111, D12317, doi:10.1029/2005JD006594, 2006.

Vogel, B., Pan, L. L., Konopka, P., Günther, G., Müller, R., Hall, W., Campos, T., Pollack, I., Weinheimer, A., Wei, J., Atlas, E. L., and Bowman, K. P.: Transport pathways and signatures of mixing in the extratropical tropopause region derived from Lagrangian model simulations, J. Geophys. Res., 116, D05306, doi:10.1029/2010jd014876, 2011.

Wang, G., Kong, Q., Xuan, Y., Wan, X., Chen, H., and Ma, S.: Development and application of ozonesonde system in China, Advance in Earth Sciences, 18, 471-475, 2003 (in Chinese).

Wang, T., Ding, A., Gao, J., and Wu, W. S.: Strong ozone production in urban plumes from Beijing, China, Geophys. Res. Lett., 33, L21806, doi:10.1029/2006gl027689, 2006.

Wang, T., Wei, X. L., Ding, A. J., Poon, C. N., Lam, K. S., Li, Y. S., Chan, L. Y., and Anson, M.: Increasing surface ozone concentrations in the background atmosphere of Southern China, 19942007, Atmos. Chem. Phys., 9, 6217-6227, doi:10.5194/acp-96217-2009, 2009a.

Wang, T., Nie, W., Gao, J., Xue, L. K., Gao, X. M., Wang, X. F., Qiu, J., Poon, C. N., Meinardi, S., Blake, D., Wang, S. L., Ding, A. J., Chai, F. H., Zhang, Q. Z., and Wang, W. X.: Air quality during the 2008 Beijing Olympics: secondary pollutants and regional impact, Atmos. Chem. Phys., 10, 7603-7615, doi:10.5194/acp10-7603-2010, 2010.

Wang, X., Li, J., Zhang, Y., Xie, S., and Tang, X.: Ozone source attribution during a severe photochemical smog episode in Beijing, 
China, Sci. China Ser. B, 52, 1270-1280, doi:10.1007/s11426009-0137-5, 2009b.

Wang, Y., Hao, J., McElroy, M. B., Munger, J. W., Ma, H., Chen, D., and Nielsen, C. P.: Ozone air quality during the 2008 Beijing Olympics: effectiveness of emission restrictions, Atmos. Chem. Phys., 9, 5237-5251, doi:10.5194/acp-9-5237-2009, 2009c.

Wang, Y., Zhang, Y., Hao, J., and Luo, M.: Seasonal and spatial variability of surface ozone over China: contributions from background and domestic pollution, Atmos. Chem. Phys., 11, 35113525, doi:10.5194/acp-11-3511-2011, 2011.

Wang, Y. X., McElroy, M. B., Wang, T., and Palmer, P. I.: Asian emissions of $\mathrm{CO}$ and $\mathrm{NO}_{\mathrm{x}}$ : Constraints from aircraft and Chinese station data, J. Geophys. Res., 109, D24304, doi:10.1029/2004jd005250, 2004.

Witte, J. C., Schoeberl, M. R., Douglass, A. R., Gleason, J. F., Krotkov, N. A., Gille, J. C., Pickering, K. E., and Livesey, N.: Satellite observations of changes in air quality during the 2008 Beijing Olympics and Paralympics, Geophys. Res. Lett., 36, L17803, doi:10.1029/2009g1039236, 2009.

WMO: Meteorology - A three dimensional science: Second session of the Commission for Aerology, WMO Bulletin, IV, 134-138, 1957.
WMO: Scientific Assessment of Ozone Depletion: 1994, Global Ozone Res. and Monit. Proj., Geneva, Switzerland, WMO Rep. 37, 1995.

WMO: Scientific Assessment of Trends in the Vertical Distribution of Ozone, Global Ozone Res. and Monit. Proj., Geneva, Switzerland, WMO Rep. 43, 1998.

Xu, X., Lin, W., Wang, T., Yan, P., Tang, J., Meng, Z., and Wang, Y.: Long-term trend of surface ozone at a regional background station in eastern China 1991-2006: enhanced variability, Atmos. Chem. Phys., 8, 2595-2607, doi:10.5194/acp-8-2595-2008, 2008.

Xuan, Y., Ma, S., Chen, H., Wang, G., Kong, Q., Zhao, Q., and Wan, X.: Intercomparisons of $\mathrm{GPSO}_{3}$ and Vaisala ECC Ozone Sondes, Plateau Meteorology, 23, 394-399, 2004 (in Chinese).

Zhang, Q., Streets, D. G., He, K., Wang, Y., Richter, A., Burrows, J. P., Uno, I., Jang, C. J., Chen, D., Yao, Z., and Lei, Y.: $\mathrm{NO}_{\mathrm{x}}$ emission trends for China, 1995-2004: The view from the ground and the view from space, J. Geophys. Res., 112, D22306, doi:10.1029/2007JD008684, 2007.

Zheng, X. and Li, W.: Analysis of the data quality observed by the ozonesonde system made in China, Journal of Applied Meteorological Science, 16, 608-618, 2005 (in Chinese). 